\title{
New bone formation in the female rabbit tibia
}

\section{Neoformação óssea em tíbias de coelhas}

\author{
Alexandre Colmanetti* \\ Kleber Fernando Pereira** \\ Renato Paulo Chopard***
}

\begin{abstract}
The current study aims to evaluate the new bone formation in polyvinylpyrrolidone (PVP) grafts inserted into the tibia of ten female rabbits. The animals were submitted to oophorectomy in order to induce an osteopenic condition and densitometrically analyzed at the beginning of the experiment, at three months and at seven months. During the 16 weeks of osseointegration, the animals were submitted to subcutaneous injections of three bone markers at one-week intervals, four weeks for each. Before the third densitometric analysis, the animals were sacrificed and material was collected for histological evaluation, in which osteoid formations and mineralized bone tissue were observed surrounding the grafts, even within the medullary cavity. Only small quantities of new bone were found in the osteopenic animals, indicating the high osteocondutivity of PVP and its efficacy in inducing osteopenia. Among the samples with no graft, a high level of disorganization of the material was observed in the oophorectomized group, confirming the efficacy of oophorectomy.
\end{abstract}

DESCRIPTORS: New bone formation; Grafts; Tibia; Rabbits.

RESUMO: O presente estudo constitui em se fazer uma avaliação da neoformação óssea em enxertos de PVP (polivinilpirrolidona) colocados em tíbias de dez coelhas. Os animais foram submetidos à cirurgia de ooforectomia para a indução de um quadro osteopênico e analisados densitometricamente no início do experimento, aos três meses e aos sete meses. Durante as dezesseis semanas de osteointegração, os animais foram submetidos a injeções subcutâneas de três marcadores ósseos, em intervalos semanais, por quatro semanas cada um; em seguida, foram sacrificados, previamente à terceira análise densitométrica, para avaliação histológica do material. Foi observada a presença de formações osteóides e tecido ósseo mineralizado envolvendo o enxerto, inclusive na região medular, em menor quantidade nos animais osteopênicos, o que indica a boa qualidade osteocondutora do PVP e a eficácia na indução de osteopenia pela menor quantidade de material ósseo encontrado. No material sem enxerto, observou-se um tecido mais desorganizado no grupo ooforectomizado, reiterando a eficácia da ooforectomia.

DESCRITORES: Neoformação óssea; Enxertos; Tíbia; Coelhos.

\section{INTRODUCTION}

The effect of estrogen on bone remodeling in human beings is better represented by decreased reabsorption than by new bone formation. Hypoestrogenism increases bone remodeling in a time-dependent manner, causing a loss of bone mass. This process is reversed through the administration of estrogen and its analogues ${ }^{2,8}$.

With the introduction of advanced techniques and the use of sophisticated bone grafting materials, it is possible to increase the volume, length and thickness of bone tissue in deficient areas and regenerate tissues that support teeth. However, such grafts are of questionable stability and complicate future implantation, often causing the implants to be inserted at less than ideal angles, thereby resulting in less acceptable restoration with poor prognosis ${ }^{4,10}$.

The influence of collagen-PVP on the repair of bone defects experimentally created in rat skeletons as well as on the expression of osteopontin and osteonectin (secreted protein, acidic and rich in cysteine - SPARC) during repeated femoral fractures in rats was evaluated. It was concluded that this material accelerates new bone formation and stimulates the healing process by increasing protein levels (as detected by the assessment of osteopontin expression) in mature osteoblasts during bone remodeling ${ }^{1}$.

The current study aimed to evaluate, through histomorphometry, new bone formation in the area

\footnotetext{
* MSc; **Undergraduate Degree in Physical Education, State University of Maringá and MSc Student in Anatomy; ***PhD, Professor - Department of Anatomy, Biomedical Sciences Institute, University of São Paulo.
} 
of the collagen-PVP graft in oophorectomized and non-oophorectomized female rabbits.

\section{MATERIALS AND METHODS}

Ten three-month-old "White New Zealand" female rabbits were selected. The animals were divided into the following groups: OVX (composed of five oophorectomized rabbits), and FOVX (composed of five non-oophorectomized rabbits).

It was determined that all animals would receive, as graft material, the collagen-PVP (Instituto de Pesquisas Energéticas e Nucleares IPEN/CNEN, São Paulo, Brazil) substance, which had been irradiated with gamma particles, on the proximal area of the tibia.

Three measurements of bone mineral density were taken in the proximal third of the tibia of each rabbit in the OVX and FOVX groups using the noninvasive dual-energy X-ray absorptiometry (DEXA) and pDEXA Sabre (Norland, Fort Atkinson, WI, USA) methods. In the last two measurements, gauging of the vertebrae was also included.

In order to create a bed for the graft material, it was determined that two cavities would be created in the media side of the tibiae, a proximal and a distal cavity, with the first approximately $10 \mathrm{~mm}$ distant from the articular surface of the knee joint and with a distance of about $3 \mathrm{~mm}$ between them. The distal cavity was filled with PVP, and the proximal cavity did not receive any aloplastic graft material, being filled only by blood clot.

The animals were submitted to a 16-week postoperative protocol in which cellular markers were injected subcutaneously [weeks 3, 4, 5 and 6: alizarin (Vetec Química Fina, São Paulo, Brazil); weeks 7, 8, 9 and 10: calcein (Vetec Química Fina, São Paulo, Brazil); weeks 11, 12, 13 and 14: tetracycline (Med Química, São Paulo, Brazil)]. Two weeks after the last application, the animals were sacrificed with an overdose of anesthetic (Univet S.A., São Paulo, Brazil) and the samples were histologically prepared.

\section{Histomorphometry}

Fluorescent light microscopy was used in order to analyze the cortical bone area selected for the graft. To determine the percentage of area occupied by each marker, the following formula was used:

$$
\text { Area }(\%)=\frac{(\text { Area occupied by each marker }) \times 100}{\text { Total area occupied by all markers }}
$$

\section{Statistical analysis}

To compare medians among more than two independent groups, as in the case of the three densitometric measurements, Fisher's variance (ANOVA) was used. Correlations among the medians of more than two groups, as in the case of new bone formation evidence from each marker, were drawn using Friedman's nonparametric analysis of variance. When comparing the medians of two independent groups, as in the case of the oophorectomized and non-oophorectomized animals, the Student's unpaired $t$-test was used, with Welch correction for the continuation. When comparing the medians of two correlated groups, as in the case of the presence or absence of the collagen-PVP graft, the Student's paired $t$-test was used.

\section{RESULTS}

In the analysis of tibias and vertebrae of the oophorectomized (group OVX) and non-oophorectomized (group FOVX) animals through bone densitometry, greater new bone formation was observed in rabbits from the second group (Graphs 1 and 2) and identification of new bone formation using alizarin, calcein and tetracycline as markers (Figure 1).

To evaluate the results of histomorphometry, we considered the interference of three external agents: the oophorectomy, the presence or absence of collagen-PVP and the duration of bone marker deposition.

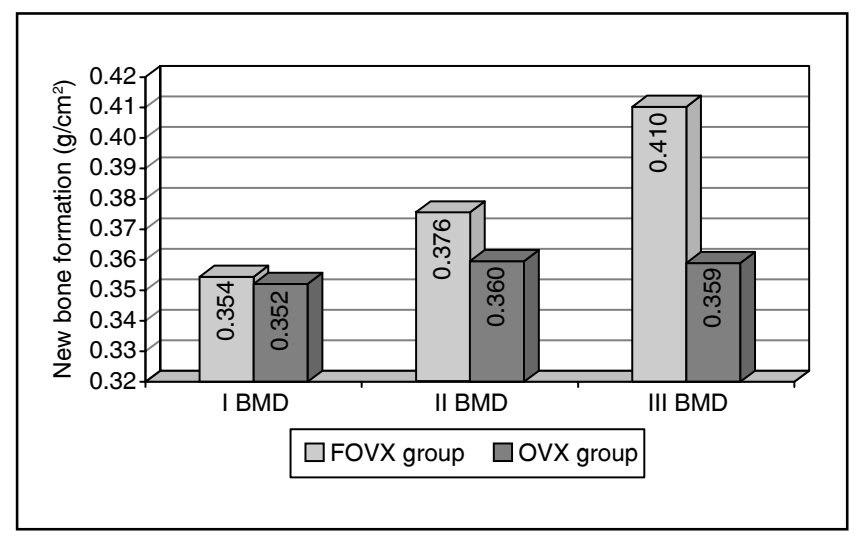

GRAPH 1 - New bone formation (in $\mathrm{g} / \mathrm{cm}^{2}$ ) in the tibia between the first and third densitometry between FOVX and OVX groups. $\mathrm{p}<0.05$. BMD: bone mineral density. FOVX: non-oophorectomized. OVX: oophorectomized. 


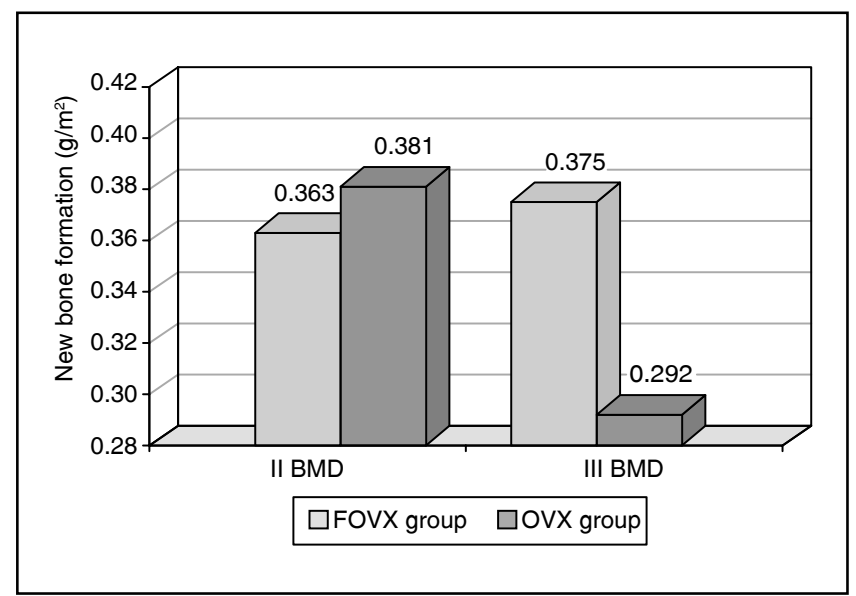

GRAPH 2 - New bone formation (in $\mathrm{g} / \mathrm{cm}^{2}$ ) in the vertebrae between the second and third densitometry, between FOVX and OVX groups. $\mathrm{p}>0.05$. BMD: bone mineral density. FOVX: non-oophorectomized. OVX: oophorectomized.

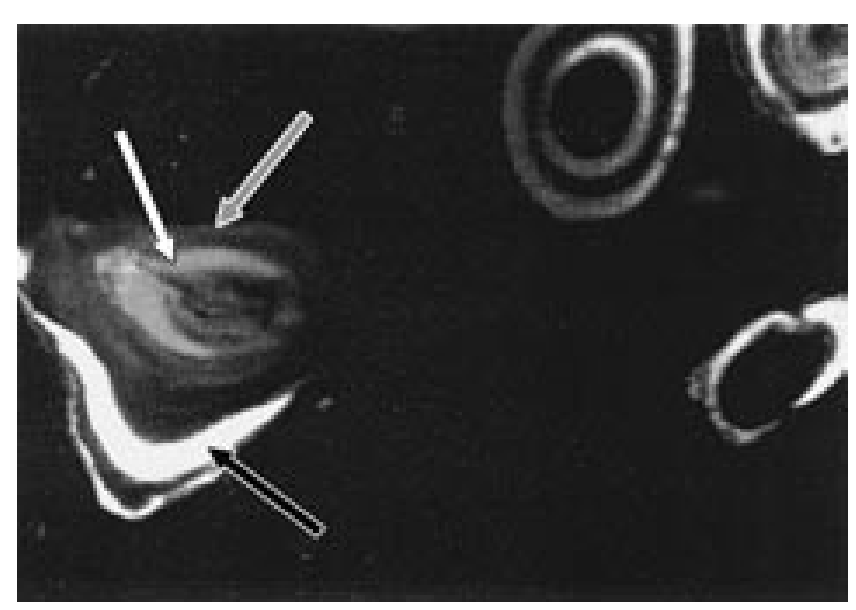

FIGURE 1 - Cross section of tibia showing different stages of osseous neoformation in oophorectomized female rabbit without PVP graft. Alizarin (grey arrow), tetracycline (white arrow) and calcein (black arrow). $100 \mathrm{X}$.

\section{Oophorectomy}

In the oophorectomy group, the calcein marker revealed that new bone formation was higher and very pronounced in the FOVX group when grafts were present, and the tetracycline marker showed that new bone formation was higher and extremely pronounced in the FOVX group when collagen-PVP was present (Table 1).

\section{Presence or absence of collagen-PVP}

In the presence of collagen-PVP, the calcein marker revealed that new bone formation was sig-
TABLE 1 - Statistical analysis using the Student's unpaired $t$-test with Welch correction.

\begin{tabular}{l|c|c}
\hline Group & $\begin{array}{c}\text { FOVX vs. OVX } \\
\text { (with } \\
\text { collagen-PVP) }\end{array}$ & $\begin{array}{c}\text { FOVX vs. OVX } \\
\text { (without } \\
\text { collagen-PVP) }\end{array}$ \\
\hline Alizarin & $\mathrm{p}=0.0829 / \mathrm{ns}$ & $\mathrm{p}=0.9581 / \mathrm{ns}$ \\
\hline Calcein & $\mathrm{p}=0.0017 /^{* *}$ & $\mathrm{p}=0.5652 / \mathrm{ns}$ \\
\hline Tetracycline & $\mathrm{p}=0.0003 /^{* * *}$ & $\mathrm{p}=0.8517 / \mathrm{ns}$ \\
\hline \hline
\end{tabular}

$\mathrm{ns}=$ not significant $(\mathrm{p}>0.05) ; \quad * *=$ very significant $(0.01>\mathrm{p}>0.001) ; * * *=$ extremely significant $(\mathrm{p}<0.001)$. FOVX: non-oophorectomized. OVX: oophorectomized.

TABLE 2 - Statistical analysis using Student's paired t-test.

\begin{tabular}{l|l|l}
\hline Group & $\begin{array}{l}\text { Presence } v s . \\
\text { absence of } \\
\text { collagen-PVP } \\
\text { (FOVX) }\end{array}$ & $\begin{array}{l}\text { Presence } v s . \\
\text { absence of } \\
\text { collagen-PVP } \\
\text { (OVX) }\end{array}$ \\
\hline Alizarin & $\mathrm{p}=0.6445 / \mathrm{ns}$ & $\mathrm{p}=0.0694 / \mathrm{ns}$ \\
\hline Calcein & $\mathrm{p}=0.0084 / * *$ & $\mathrm{p}=0.0700 / \mathrm{ns}$ \\
\hline Tetracycline & $\mathrm{p}=0.7261 / \mathrm{ns}$ & $\mathrm{p}=0.0393 /^{*}$ \\
\hline \hline
\end{tabular}

$\mathrm{ns}=$ not significant $(\mathrm{p}>0.05) ; *=$ active significance $(0.05>p>0.01) ; * *=$ very significant $(0.01>p>0.001)$. FOVX: non-oophorectomized. OVX: oophorectomized.

TABLE 3 - Statistical analysis using Friedman's test.

\begin{tabular}{|c|c|}
\hline Groups Markers & $\begin{array}{l}\text { Calc. vs. aliz. } \\
\text { vs. tetrac. }\end{array}$ \\
\hline FOVX (without collagen-PVP) & $\mathrm{p}=0.0008 / * * *$ \\
\hline FOVX (with collagen-PVP) & $\mathrm{p}=0.0085 / * *$ \\
\hline OVX (without collagen-PVP) & $\mathrm{p}=0.0008 / * * *$ \\
\hline OVX (with collagen-PVP) & $\mathrm{p}=0.0008 / * * *$ \\
\hline
\end{tabular}

$* *=$ very significant $(0.01>\mathrm{p}>0.001) ; * * *=$ extremely significant ( $\mathrm{p}<0.001)$. FOVX: non-oophorectomized. OVX: oophorectomized. Calc.: calcein; aliz.: alizarin; tetrac.: tetracycline.

nificantly higher in the FOVX group when grafts were present, and the tetracycline marker showed that new bone formation was higher without graft in the OVX group, although with low significance (Table 2).

\section{Duration}

Higher, extremely significant, new bone formation rates were observed during the calcein applications in both groups, regardless of the presence or absence of the graft (Table 3). 


\section{DISCUSSION}

There are few studies on the limitations of estrogen. Estrogen deficiency is not a contraindication for the use of dental implants, requiring a longer waiting period for osseointegration. The same applies for grafts, since the osteopenic condition probably inhibits new bone formation ${ }^{3,6,9}$. In the present study, considering the bone formed around the grafts in the medullary region, the only difference between oophorectomized and non-oophorectomized animals was that the quantity of bone was lower in the first group. These findings are in agreement with those of Pan et al. ${ }^{7}$ (2000), who studied oophorectomized female rats and found a progressive decrease in the contact area between the dental implant and the supporting bone, especially in the medullary region, which can affect the stabilization of the implant ${ }^{7}$.

The results obtained in the evaluation of the new bone formation rates show that they were significantly higher in the presence of collagen-PVP in the FOVX group during calcein applications. A similar improvement in new bone formation was observed when collagen-PVP was present in the bone defects created in rat skeletons. These findings are in agreement with those of Chimal-Monroy et al. ${ }^{1}$ (1998), describing that the presence of collagen-PVP during the repair of fractures in rat femurs resulted in improved rates during all phases of new bone formation, as well as in an increased expression of osteopontin and SPARC. In contrast, collagen alone induced no such improvement.

\section{REFERENCES}

1. Chimal-Monroy J, Bravo-Ruiz T, Furuzawa-Carballeda GJ, Lira JM, de la Cruz JC, Almazan A, et al. Collagen-PVP accelerates new bone formation of experimentally induced bone defects in rat skull and promotes the expression of osteopontin and SPARC during bone repair of rat femora fractures. Ann N Y Acad Sci 1998;857:232-6.

2. Dempster DW. Bone remodeling. In: Riggs BL, Melton III LJ. Osteoporosis: etiology, diagnosis, and management. $2^{\text {nd }}$ ed. Philadelphia: Lippincott Raven; 1995. p. 75.

3. Fujimoto T, Niimi A, Nakai H, Ueda M. Osseointegrated implants in a patient with osteoporosis: a case report. Int J Oral Maxillofac Implants 1996;11:539-42.

4. Hoexter DL. Bone regeneration graft materials. J Oral Implantol 2002;28:290-4.

5. Instituto de Pesquisas Energéticas e Nucleares - IPEN/ CNEN-SP. Biocompatibilidade in vitro de membranas de hidrogéis preparadas em diferentes fontes de radiação (manual de procedimentos internos); 1998.
At no time did we find signs of inflammation in areas adjacent to or connected to the grafted material, in accordance with the results from a study on the biocompatibility of the material conducted at IPEN/CNEN ${ }^{5}$ (Energetic and Nuclear Research Institute/National Committee for Nuclear Energy). In the present study, the presence of mineralized bone tissue surrounding the graft in the medullary region, even in rabbits that proved to be osteopenic, suggests that collagen-PVP has good osteoconductivity. However, our findings are inconclusive and further studies are warranted in order to determine the appropriate clinical application of this material.

\section{CONCLUSIONS}

Considering the results expected, the study itself and the results obtained, we can conclude that:

1. There was efficient osteopenic induction, as evidenced by the densitometric analysis. This was due to the lower bone deposition rates in the animals submitted to oophorectomy.

2. The presence of the collagen-PVP graft, in both osteopenic and non-osteopenic animals, showed no positive influence on the induction of new bone formation. This was confirmed by the layer of compact bone surrounding the graft in the medullary region, although this layer was quite thin in the osteopenic animals.

6. Lugero GG, de Falco Caparbo V, Guzzo ML, Konig B Jr, Jorgetti V. Histomorphometric evaluation of titanium implants in osteoporotic rabbits. Implant Dent 2000;9:303-9.

7. Pan J, Shirot T, Ohno K, Michi K. Effect of ovariectomy on bone remodeling adjacent to hydroxyapatite-coated implants in the tibia of mature rats. J Oral Maxillofac Surg 2000;58:877-82.

8. Parfitt AM, Drezner MK, Glorieux FH, Kanis JA, Malluche $\mathrm{H}$, Meunier PJ. Bone histomorphometry: standardization of nomenclature, symbols, and units. Report of the ASBMR Histomorphometry Nomenclature Committee. J Bone Miner Res 1987;2:595-610.

9. Riggs BL, Melton LJ. Involutional osteoporosis. J Bone Miner Res 1986;314:1676-86.

10. Turner RT, Riggs BL, Spelsberg TC. Skeletal effects of estrogen. Endocr Rev 1994;13:275-300.

Received for publication on Dec 15, 2003 Sent for alterations on Mar 18, 2004 Accepted for publication on Apr 30, 2004 